\title{
Home Work in Thailand
}

\author{
Challenges to Formalization
}

\author{
Narumol Nirathron
}

This chapter analyses challenges in the transition of home work to the formal economy in Thailand. * It draws on data from different studies on the home work situation, including statistical surveys and findings from a 2015 study covering over 3,00o home workers and 220 employers in 26 job-types from 7 industries, taking into account a series of efforts by the Thai government to provide protection for home workers, the International Labour Organization's (ILO's) Convention No. 177 and Recommendation No. 184-Home Work Recommendation, 1996 (No. 184) as well as Recommendation No. 204 concerning the Transition from the Informal to the Formal Economy.

In most countries, home-based work originated from manufacturing that involved the use of raw materials from the farming sector. The work products were, for the most part, food and local goods. Over time, the manufacturing process and global competition changed; as a result, home work now is no longer confined to products derived from the farming sector, but includes products in the industrial and service sectors. ${ }^{1}$

Home work is a subcontractual form of production. The relationship between the employer and the home worker is not that of an employeremployee, but more like that between an employer and a subcontractor. There are several reasons for the existence of home work: such as, for instance, that a large number of workers are unable to enter the formal economy, for different reasons. Rapid changes in economic conditions and consumption preferences have forced the manufacturing system to adopt a more flexible and practical

* This paper is a revised version of a presentation at the International Conference on "Longterm Perspectives on Home-based Work", organized by the Centre for Women's Development Studies (CWDS), Delhi, the Swedish Labour Movement Archive and Library (ARAB), and Women in Informal Employment: Globalizing and Organizing (WIEGO), Stockholm, 22-24 May 2018.

1 Martha A. Chen, Informal Economy Monitoring Study Sector Report: Home-Based Workers (Cambridge, 2004), pp. 1-2; Wendy Cunningham and Carlos R. Gomez, The Home as Factory Floor: Employment and Remuneration of Home-based Worker, available at http:// elibrary.worldbank.org/doi/book/10.1596/1813-9450-3295, last accessed 23 August 2015.

(C) NARUMOL NIRATHRON, 2022 | DOI:10.1163/9789004499614_011

This is an open access chapter distributed under the terms of the CC BY-NC-ND 4.o license.

Narumol Nirathron - 9789004499614 
approach. The subcontractual system also allows business operators to pass along production risks and costs to home workers, thereby saving significantly on costs of labour and storage of goods. It also allows manufacturers to set more competitive product prices for consumers. Therefore, it is not very surprising that the subcontractual approach has become a global practice. At the same time, it has led to greater exploitation of labour in different guises. In subcontractual arrangements, the stakeholders are not confined to employers and contracted workers, but include retailers who enjoy considerable bargaining power in the supply chain and consumers who want cheaper goods.

In 1996, the International Labour Organization (ILO) adopted the Home Work Convention (No. 177) and Home Work Recommendation (No. 184), both emphasizing compliance to international labour standards and respect for workers' rights. Convention 177 is primarily concerned with the protection and promotion of home workers, and the government's role in carrying out necessary acts pertaining to both mandates. The Convention is complemented by Recommendation 184 , which provides guidelines to achieve the mandates.

Thailand, which has not ratified Convention 177, nevertheless initiated legal protection of home workers with the Ministerial Regulation on Protection of Home Workers B.E. 2547 (2004), followed by enactment of the Home Workers Protection Act B.E. 2553 (2010), which has been enforced gradually.

In 2015, the ILO's Recommendation 204 concerning the Transition from the Informal to the Formal Economy was adopted. Its main objectives are to promote the transition of workers and economic units from the informal to the formal economy, and to prevent informalization of formal economy jobs. The focus of the Recommendation is on establishing legal and institutional mechanisms designed to promote fulfilment of decent work and development through collaboration between the public sector and different stakeholders. For home workers already protected by legal provisions, the transition means greater legal recognition and access to funding sources necessary for developing their enterprises or working environments.

This chapter presents the situation of home work from the perspective of the transition from the informal to the formal economy using data from the 2015 study, covering 3,105 home workers and 226 employers in 26 types of jobs from 7 industries. In addition, documents related to the home work situation in Thailand are analysed, as well as the essence of labour protection laws, including social protection and welfare systems, for home workers in Thailand. How these serve as a significant vehicle for the transition is analysed, in addition to the ways and means of the transition in the light of Recommendation 204. The chapter unfolds the employment situation; the measures of protection, 
promotion, and development of home workers; and the opportunities and challenges that result from such transitions.

\section{Convention 177 and Recommendation 184: Connecting Core Labour} Standards and a Decent Work Agenda

The ILo's Home Work Convention 177 and Home Work Recommendation 184, detailing labour standards and worker rights, were adopted in 1996. Convention 177 offers a framework for protecting home workers, ranging from fundamental tasks such as collecting statistics to formulating national policy pertaining to labour and social protection as well as labour development. ${ }^{2}$ Recommendation 184 provides guidelines for implementing the Convention by defining home work, the home worker, and the employer, and formulating core home work policy and its implementation through tripartite mechanisms and collection of data on home workers, employers, and intermediaries. It values the role of employers as compilers of data on home workers and information that home workers should know. The Recommendation also mentions the right to organize and bargain collectively, measures to encourage organization and collective bargaining, and the fixing of minimum wage rates-preferably by collective bargaining or competent authorities, or through agreement between the home worker and employer. At the same time, the remuneration rates should be comparable to those received by workers in formal enterprises. Home workers should also receive welfare, just like other general workers. ${ }^{3}$

Therefore, Convention 177 serves as an international instrument connecting core labour standards and a decent work agenda, promoting equal treatment for home workers as for other regular workers. As of 2019, ten countries have ratified the Convention; Thailand has not yet done so.

2 International Labour Organization (ILO), Home Work Convention, 1996 (No. 177), available at https://www.ilo.org/dyn/normlex/en/f?p=NORMLEXPUB:1210o:o::NO:::P1210o_ INSTRUMENT_ID:312322, last accessed 23 August 2019.

3 International Labour Organization(ILO), Home WorkRecommendation, 1996 (No. 184), available at https://www.ilo.org/dyn/normlex/en/f?p=NORMLEXPUB:\%2O12100:O::NO:1210o:P1210O_ INSTRUMENT_ID:312322:NO, last accessed 23 August 2019. 


\section{Home Work in Thailand before the Enactment of the Home Workers Protection Act B.E. 2553 (2010)}

The issue of subcontractual workers or home workers received a certain amount of attention before the implementation of Thailand's Sixth National Economic and Social Development Plan (1987-1991). The Plan specifically mentioned measures to promote the subcontracting system for workers in different provincial towns. ${ }^{4}$ In $1985 / 86$, the Department of Labour, then under the Ministry of the Interior, prepared a report on the employment conditions and labour of home workers. ${ }^{5}$ The next year, the Justice and Peace Commission of Thailand (JPCT) launched a project to study a shophouse-based tailoring and sewing business in the Dindaeng district of Bangkok as well as a public awareness-raising campaign about how sub-contractual employment might lead to labour exploitation. ${ }^{6}$

From 1988 to 1996, the ILO conducted a project on rural women workers in the putting-out system in Thailand. The eight-year project aimed to promote social protection among home workers and strengthen institutional support for the concerned organizations. Included in it were studies on employment conditions; problems of home work; home worker and employer characteristics in the Northern and Northeastern Regions as well as Bangkok; and the roles of governmental and non-governmental organizations and labour unions in protecting, promoting, and developing home workers. ${ }^{7}$ As a result, home-based and non-governmental organizations in Bangkok and Northern Thailand established a network to promote social protection for home workers, own account workers, and other informal workers, known as the Informal Workers Network or HomeNet Thailand, ${ }^{8}$ which campaigned for social protection of home workers and other workers in the informal sector. The Network

4 National Economic and Social Development Board, The Sixth National Economic and Social Development Plan (1987-1991) (Bangkok, n.d.,), p. 94, available at https://www.nesdc.go.th/ nesdb_en/ewt_w3c/ewt_dl_link.php?filename=develop_issue\&nid=3781, last accessed 23 August 2017.

5 Kongvichakarn Lae Pan [Academic and Planning Division], Sarubponkarnsuksakarnjangngan Lae Sapapkantumngan Kongpurubnganpaitumteeban Naipratedthai [Summary Findings of Employment and Working Conditions of Home-based Workers in Thailand] (Bangkok, 1986).

6 Puthai (Special Issue), Rangngannokrabobnaikrungthepmahanakorn [Informal Workers in Bangkok] (Bangkok, 1994).

7 Lucita Lazo (ed.), Practical Actions for the Social Protection of Homeworkers in Thailand (Bangkok, 1996), pp. 94-110.

8 Homenet Thailland, available at https://homenetthailand.org/, last accessed 27 May 2021. 
evolved into the Centre for Study and Promotion of Home Workers in 1997, and was registered in 2003 as the Foundation for Labour and Employment Promotion (FLEP). The last-mentioned foundation has played an important role in regularly campaigning for, and promoting, the rights of homeworkers and others in the informal sector.

As changes in the manufacturing system and its impact on workers became more evident, attempts were made in the public and the non-government sector to enact new laws to protect, promote, and develop home workers. Under the Labour Protection Act, B.E. 2541 (1998), "home work" was deemed potentially eligible for labour protection through ministerial regulations different from those broadly prescribed in the Act.

In 2003, the Foundation for Labour and Employment Promotion, in collaboration with Homenet Thailand, NGO s and labour lawyers, drafted a bill designed to protect, promote, and develop home-based workers. ${ }^{9}$ One year later, the Thai Ministry of Labour issued a Ministerial Regulation on Protection of Home Workers. However, enforcement was limited in several ways. Both employers and home workers felt that compliance with the Regulation created increased burdens, while government officials experienced certain constraints in implementing the Regulation. ${ }^{10}$ Attempts towards a home workers' protection bill continued unabated. Eventually, at the same time as the Ministry of Labour submitted a home workers' protection bill to the government in 2007 for approval, HomeNet Thailand and the Foundation for Labour and Employment Promotion submitted a different bill to the government covering protection, promotion, and development of home workers.

The Ministry of Labour bill aimed to provide protection to home workers as widely and fairly as possible, while that of HomeNet Thailand was designed to protect, promote, and develop home workers, as well as encourage worker organization and participation of all parties concerned in formulating policy and laws to ensure fairness and benefits for all. ${ }^{11}$ The Homeworkers Protection Act B.E. 2553 (2010) was adopted on 29 September 2010 and promulgated on 15 May 2011.

9 Bundit Thanachaisethawut (ed.), Leowlunglaena Kodmaikumkrong Sitthipurubnganpaitumteeban [Looking Backward and Forward: The Law on the Protection of the Rights of Home-based Workers] (Bangkok, 2007).

10 Chalit Meesithi and Poonsap Suanmuang Tulaphan, Purubnganpaitumteeban Nai Pratedtai: Sitthi Lae Karn Ronnarong Nayobai [Legal Rights of Home Workers in Thailand] (Bangkok, 2006), pp. 24-25.

11 Thanachaisethawut(ed.),Leowlunglaena KodmaikumkrongSitthipurubnganpaitumteeban [Looking Backward and Forward], p. 6. 


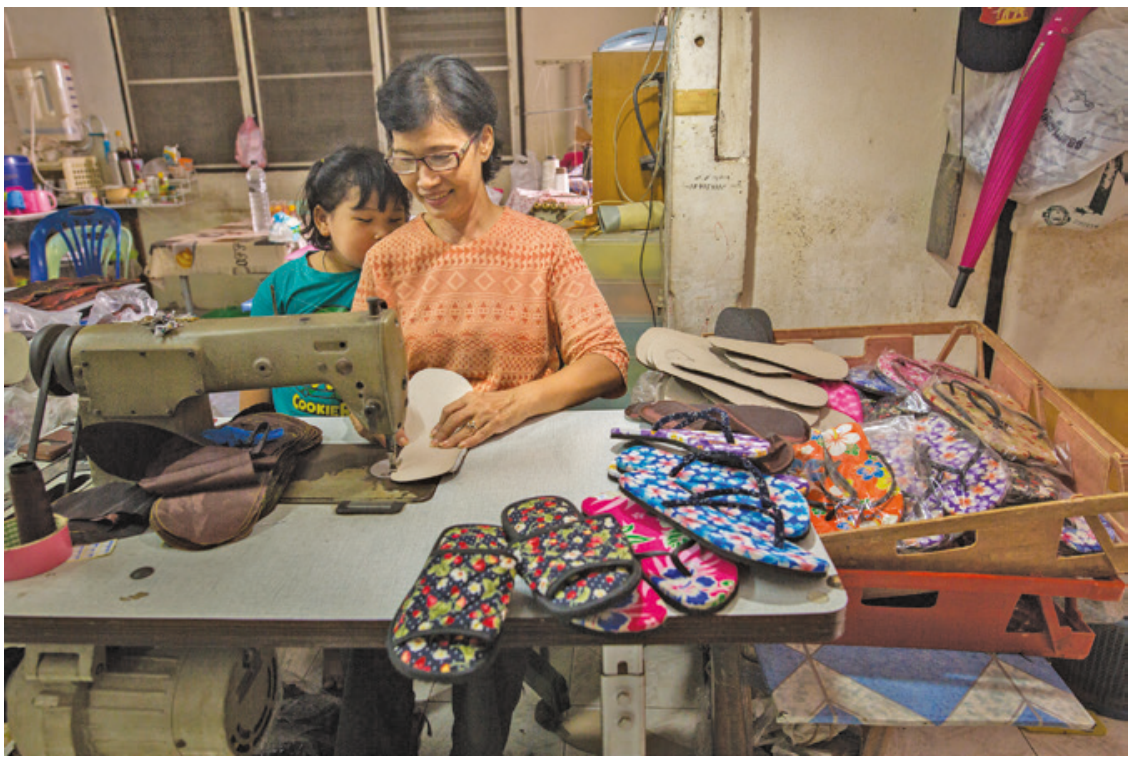

FIGURE 9.1 BANGKOK, THAILAND: Rattana Chalermchai works at her home-based sewing machine where she is able to enjoy the company of her granddaughter, Silisak. A former factory worker, Rattana was laid off during the economic crisis in 1997. She now supplies hand-made flip-flops to a resort. She is a long-time member of HomeNet Thailand and has contributed to several policy campaigns for informal workers, including the Universal Healthcare Coverage Scheme PHOTO: PAULA BRONSTEIN/GETTY IMAGES REPORTAGE

Prior to this Act's enforcement, statistical surveys of home workers conducted by the National Statistical Office in 1999, 2002, 2005, and 2007, all confirmed the persistence of low compensation, lack of employment continuity, and work safety problems. The National Statistical Office classified home workers into three groups: those who receive work directly, their assistants who are unpaid workers, and (sub)contractual workers. The first group was the largest in number. The survey of $2007,{ }^{12}$ the last year in the survey series, revealed that 0.014 per cent of Thai households were engaged in home work. The percentage of home workers was 0.012 per cent of employed persons in the same year. Over three-fourths of home workers were female, with more than 6o per cent belonging to the 30-49 years age group. In terms of educational qualifications, 75.4 per cent had completed primary school, and 11.8 12 National Statistical Office, The 2007 Home Work Survey (Bangkok: National Statistical
Office, 2007). 
per cent had completed lower secondary school. On average, they worked 7.6 hours a day, but 29.1 per cent of them worked more than 9 hours each day. With regard to remuneration, 84.7 per cent mentioned that the compensation was fixed by the employer, while 9.5 per cent set their own wage rates and only 2.8 per cent had the rate fixed through common agreement. Among those who received home work, 85.7 per cent received work directly. On top of the list of industries with the largest number of home workers was garment, clothes, and textile (45.2 per cent); followed by wood and paper products (8.6 per cent); jewellery (8.1 per cent); food, beverages, and tobacco; leather goods and other goods (16.4 per cent); wholesale, retail, agriculture, and other sectors (12.7 per cent). The annual average income of home workers was 40,555 baht (US $\$ 1,336.24) \cdot{ }^{13}$ On work-related issues, work safety was mentioned most often, followed by low compensation, late payment, and irregular work supply. Assistance most needed was regular work supply, protected compensation, and funding support. The workers also needed further skills training and work improvement, guidance, and health education to meet work safety norms and behaviour protocols. Only 5.1 per cent of them belonged to any association. Those among them who were not affiliated with any organized group stated that they lacked the time for participation, they were satisfied with the compensation they received, and they believed that joining a group would not increase their income. B.E. 2553 (2010) and Social Protection

The passage and enforcement of the Home Workers Protection Act B.E. 2553 $(2010)^{14}$ was a clear and important step towards protecting, promoting, and developing home workers. Home workers, considered as informal workers, ${ }^{15}$ were henceforth legally protected by a specific law. Admittedly, the protection was still rather limited. For instance, the law provides protection only for industrial work, and service work is excluded. Any step taken towards extending protection to other work categories must be prescribed by ministerial

\footnotetext{
13 The historical exchange rate was 30.35 baht $=$ US $\$ 1$.

14 Krom Sawasdeekarn Lae Kumkrong Rangngan [Department of Labour Protection and Welfare], Phrarachabunyat Kumkrongrangngan Rubnganpaitumteeban [Home Workers Protection Act, B.E. 2553 (2010) and Explanations] (Bangkok, 2013).

15 Informal workers are workers who are not subject to protection under the Labour Protection Act and are unaffiliated with the Social Security Fund under section 33.
} 
regulations. The drafting of secondary laws related to occupational safety and health is still in progress. The objective of the Home Workers Protection Act is to lay down measures for supervising, controlling, and protecting treatment of workers by employers, providing occupational safety, and offering remedies when work accidents or injuries occur. The Act also prescribes the establishment of a Home Work Protection Committee that will recommend measures to protect, promote, and develop home workers. Its core functions are defining, registering, and reporting different aspects of labour protection, including the rights and duties of home workers and employers, remuneration, work performance safety, protection and promotion mechanisms, labour inspection, and penalties. In many ways, the Act is in line with Convention 177 and Recommendation 184, which similarly offer guidelines for labour protection, home worker and employer rights and duties, remuneration, registration and reporting, work safety, and labour inspection.

The Home Workers Protection Act defines home work as limited to industrial enterprises or other work as prescribed by ministerial regulations. It also prescribes different aspects of employers' and home workers' rights and duties. For instance, a work contract must specify the following details: contact addresses; agent or subcontractor (if any); rate of remuneration and method of computation; type, quantity, and value of home work; scheduled dates of commencement and completion of each work lot; scheduled delivery date of the work; and date of payment. The law also sets conditions for terminating employment and demanding a performance bond or security against damage.

Regarding remuneration, the Act states that it shall not be less than that stipulated by the labour protection law for work of the same nature and quantity, without any discrimination. Payment of remuneration shall be made within seven days of the date of delivery as per the Act, while Recommendation 184 cites one month as the limit for timely payment. Thai law forbids employers from deducting from workers' remuneration except for payment of taxes and compensation for damages or late delivery penalties. The deduction shall not be more than 10 per cent of the remuneration, and consent must be obtained from the home worker.

The Home Workers Protection Act forbids pregnant women and children under 15 years of age to carry out work that may be hazardous to their health and safety as prescribed in ministerial regulations. It bans work that is dangerous to health and safety as prescribed by ministerial regulations. It also prohibits engaging home workers to perform tasks involving hazardous materials under the Hazardous Substance Act B.E. 2535 (1992), projects producing potentially hazardous vibrations or involving extreme heat or cold, and other potentially hazardous duties that may affect health or the environment. It is 
forbidden to procure or deliver potentially hazardous raw materials, equipment, or other accessories to carry out the work. Home workers must be given warning notice of the potential dangers of using raw materials, equipment or other accessories associated with projects, as well as offered protective and remedial measures against such dangers, and adequate protective equipment suited to the nature of the work. The employer shall be responsible for medical, rehabilitation, and funeral expenses if home workers suffer from work-related sickness or accidents, in compliance with the criteria, method, and rates prescribed by ministerial regulations.

Nevertheless, a number of issues related to worker protection, remuneration, and safety remain unaddressed in Thai law. In current Thai law, home work is confined to industrial enterprises and does not include the service industry. Nor does it mention the role, duty, and responsibility of those who act as intermediaries concerning payment of remuneration and delivery of records of work. With regard to remuneration, the Thai law does not mention the use of collective bargaining as a primary means to fix the rate of remuneration as a preferable option or to determine compensation for operational costs, such as utilities, and the time spent in maintaining machinery and equipment.

Tools of Implementation: Supervision and Protection, Promotion and Development Mechanisms for Home Work

The Home Workers Protection Act stipulates that there shall be a tripartite organization called the Home Work Protection Committee, consisting of the Permanent Secretary for Labour as chairperson and representatives from public agencies, employers, home workers, and experts as members, with the Director-General of Labour Protection and Welfare serving as member and secretary. The Committee's duties are to offer recommendations to the minister about protecting, promoting, and developing home workers; determining home work remuneration rates; encouraging employers and home workers to establish good practice guidelines; promoting cooperation among governmental agencies, the private sector, and other concerned organizations; monitoring home work-related operations of all concerned sectors; and reporting its performance to the cabinet at least once annually, while releasing information to the general public.

The Home Workers Protection Act does not mention forming any national policy on home work, statistical labour surveys covering home workers, registering employers and intermediaries, eliminating constraints or obstacles 
facing home workers seeking to organize, or measures to encourage collective bargaining in the determination of conditions of work.

\subsection{Dispute Settlement and Penalties}

Under the Home Workers Protection Act, home work-related disputes come under the jurisdiction of the Central Labour Court, while penalties differ from charge to charge. Penalties take the form of fines and/or imprisonment.

After the Act came into force, in 2011, the Foundation for Labour and Employment Promotion conducted a survey of 105 home workers who were members of the informal worker network in nine job categories ${ }^{16}$ from seven provinces $^{17}$ in the Northern, Northeastern, Central, and Southern regions, and the Bangkok Metropolitan Area (BMA). Home worker characteristics were found to be generally in line with the 2007 survey. The majority of home workers were female (88.6 per cent) with primary school diplomas (58.1 per cent), and in the age-group 31-45 years (56.2 per cent). Most (67.6 per cent) had adopted home work as their main occupation. Some of them (16.2 per cent) had experienced pay deductions because their work was inadequate or the material was damaged or broken; usually, they were given advance notice about the deductions. Over one-third received remuneration upon work delivery, while more than 40 per cent were paid within seven days after delivery. More than half the home workers stated that their pay was lower than it should be, ${ }^{18}$ and that they received the same pay for urgently required work. Other problems included: late payment, employers stopping work mid-project, lack of payment, unjustified pay deductions, and termination without prior notice with workers uncompensated for damages. There were cases of discrimination, as when some female workers received less pay than their male counterparts for the same duties. ${ }^{19}$

16 The nine job categories were: shoe-stitching, organdy embroidery, garment-making, shoe-making, garment-sewing, gem-polishing, toddy palm-peeling, hijab embroidery, and anchovy-gutting.

17 Since 2011, there have been 76 provinces in Thailand, not including the вмA.

18 Research revealed that payment for one bag of anchovy-gutting was 30-40 baht (US\$ 0.99-1.32) for thirteen hours of work. Peeling toddy palms earned 5o baht (US\$ 1.65) for six hours of work. Gem-cutting earned 130 baht (US\$ 4.28) for twelve hours of work. Embroidery of head-scarves earned 16o-25o bahts (US\$ 5.27-8.24) for ten hours of work. The minimum wage in Thailand is $159-221$ baht (US\$ 5.24-7.28).

19 Poonsap Suanmuang Tulaphan et al., "Rangngannokrabob Lae Karnkumkrongthangsungkom: Koraneesuksa Purubnganpaitumteeban" [Informal Workers and Social Protection: Case Studies of Home-based Workers], in N. Ativanichpong (ed.), Rangngan Kub Kwammaipentham: Punha Lae Tang-ok [Labour and Inequality: Problems and Remedies] (Bangkok, 2012), chapter 3, p.1-64. 
Most home workers did not directly access work from the source. Work was mostly obtained from business operators such as garment wholesalers and retailers (33.3 per cent), followed by group agents ( 25.7 per cent), and contractors/subcontractors (22.9 per cent). The lowest rate of work obtained was from manufacturers (18.1 per cent). There were no written contracts; instead, verbal agreements were made between employers and home workers. The home worker did not obtain work directly from the manufacturer and knew little or nothing about the real employer's name or address. When a non-payment issue arose, the intermediary often claimed that the business owner (the real employer) did not make the payment, resulting in his own inability to pay. Home workers were unable to verify these claims. Some employers did not provide protective gear appropriate to assignments or information about potential risks. With regard to the remuneration rate, the study found that it was fixed by the employer. ${ }^{20}$

The first Home Work Protection Committee was appointed in 2014. In 2016, it issued a notification on the rate of remuneration to ensure that home workers are paid as prescribed by the law, not less than the minimum wage. A second committee was formed in 2017 and participated in an ILO action research project to enforce the Home Workers Protection Act in Thailand. A third committee was appointed in 2019.

In practice, the Home Workers Protection Act is not fully enforceable, for several reasons. The precise definition of home work and employer remains moot. Ministerial regulations necessary for its enforcement are not fully in place, such as on the nature and type of work forbidden to home workers, as well as the criteria, procedures, and payment for medical care, rehabilitation, and funeral expenses for workers who fall ill, are injured or killed by equipment supplied by the employer or due to the employer's failure to provide necessary protective equipment. Some home workers and employers are unaware of the existence of these laws and the relevant rights of protection and employment supervision. In 2019, the Department of Labour Protection and Welfare was in the process of revising and amending the Home Workers Protection Act B.E. 2553 (2010) in light of the changing employment situation. ${ }^{21}$

20 Ibid.

21 An officer of the Department of Labour Protection and Welfare, Ministry of Labour, Thailand, interviewed by the author under the condition of anonymity, Bangkok, 11 August 2019. 
Home workers are entitled to social protection ranging from health care, income security, and personal development. They receive health and medical welfare and health protection from the National Health Insurance Scheme. They are also covered by the Social Security system, although not on a compulsory basis. A home worker between the ages of 15 and 60 may apply for insurance on a voluntary basis under section 40 of the Social Security Act B.E. 2533 (1990). There are three options to choose from, each with a different rate of contribution and benefits with different levels of government support (Table 9.1).

In addition, the National Savings Fund was created to allow self-employed persons with little or no possibility of access to retirement savings to join, enabling them to receive pensions after the age of 60 . Members of the Fund should be between 15 and 60 years of age, and should not be beneficiaries of any other retirement fund with contributions from the state or employers. Each member contributes at least 50 baht monthly to the Fund but not more than 13,200 baht annually. The government will reimburse members according to their age at a rate proportional to their contribution to the Fund. In addition, if in any given year they are unable to contribute, the National Savings Fund will retain their membership but not make contributions on its part. ${ }^{22}$

With regard to accessing funding sources, the Department of Employment, Ministry of Labour has established a revolving fund, from which home workers may request loans for procuring production raw materials and equipment or to extend production for their livelihoods. Those entitled to borrow are individual home workers or groups of not less than five home workers registered at the Department of Employment with specified employers and workplace addresses. The loan ceiling is 50,000 baht for individuals and 200,00o baht for groups. Each loan is charged an annual interest rate of 3 per cent. The loan repayment period is from two to five years. As of 2019, 864 cases of individual/ groups of home workers were registered at the Department of Employment, making up a total of 5,508 members. The Department had approved loans to 427 groups to the extent of 41,516 , ooo baht (US $\$ 1,367,907 \cdot 75) .{ }^{23}$

For personal development, home workers receive support from the Ministry of Labour's Department of Skill Development, and training through nonformal and informal education provided by the Ministry of Education.

22 National Savings Fund, available at https://eservice.nsf.or.th/privilege/list, last accessed 23 August 2019 .

23 An officer of Employment Promotion Division, Ministry of Labour, Thailand, interviewed by the author under the condition of anonymity, Bangkok, 11 August 2019. 


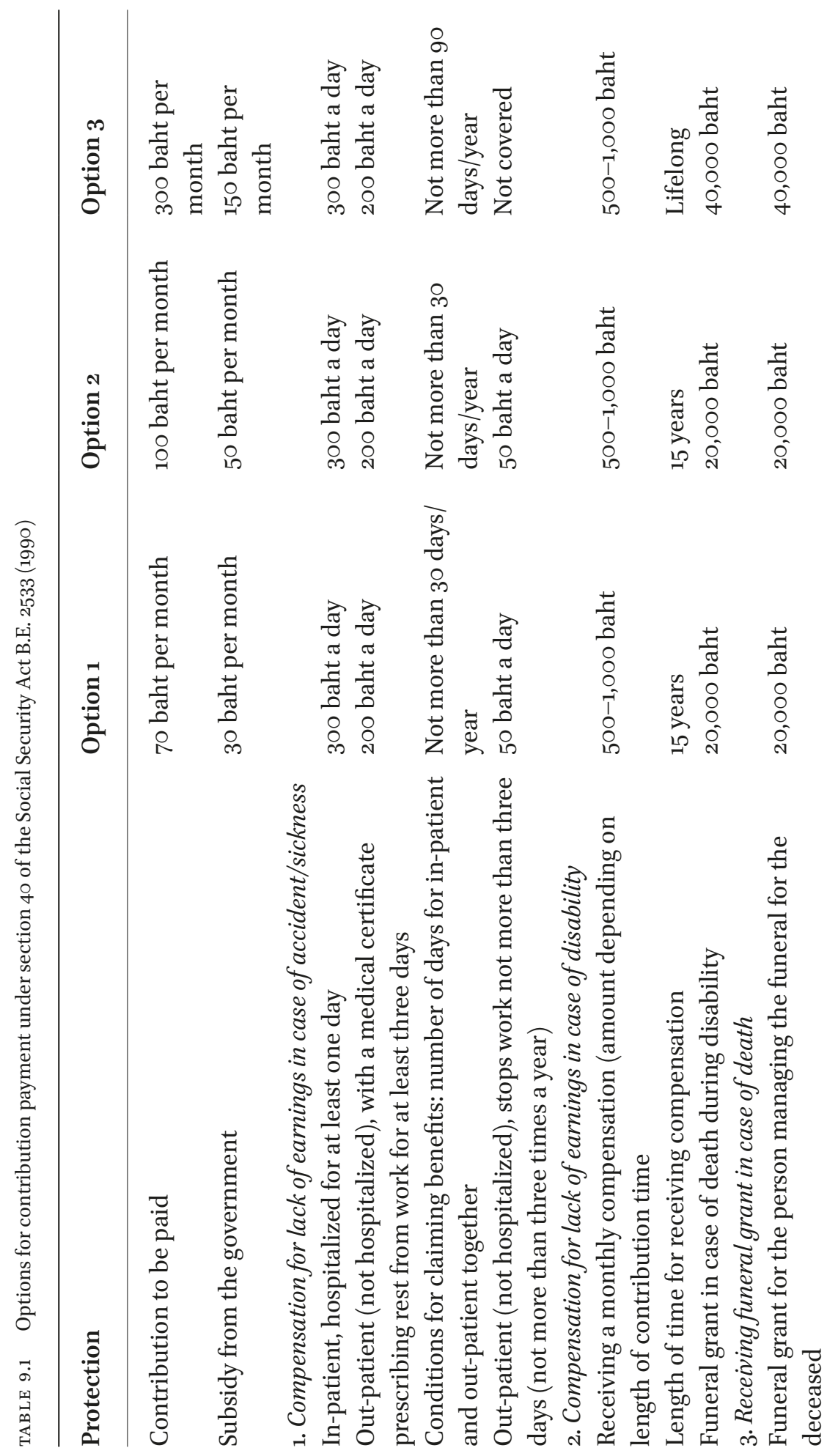




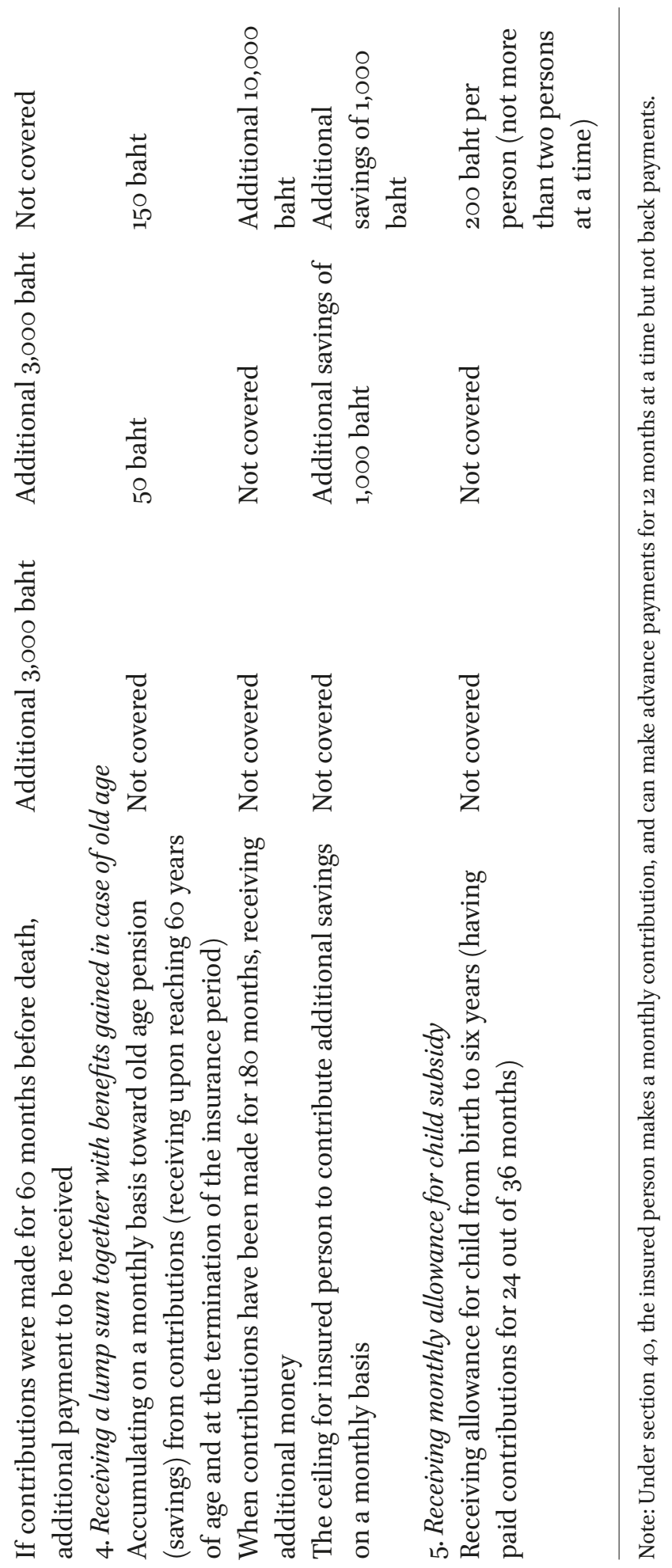


Formalization of the informal economy is based on the idea that the existence of informal work leads to violation of worker rights, and poses an obstacle to decent work and inclusive development. Therefore, it is critical that appropriate measures be established urgently to effect the transition of worker and economic units from informal to formal sectors of the economy. ${ }^{24}$ In June 2015, at its 104th session, the International Labour Conference adopted Recommendation 204, concerning the Transition from the Informal to Formal Economy. Its main objectives are to move workers and economic units from the informal to the formal economy, and to prevent informalization of formal economy jobs. Recommendation 204 suggests important principles for the transition to the formal economy, namely, emphasizing the diversity of economic units and workers; designing legal and policy frameworks facilitating the transition; and coordination with national development strategies as well as poverty reduction strategies, inclusive growth, and support for generating decent jobs in all dimensions. ${ }^{25}$ It affirms application of the Recommendation through a combination of legal mechanisms, enforcement measures, collective agreement, planning and policy development, coordination between government agencies at different levels and stakeholder groups, building institutional capacity, resource mobilization, and other measures in line with national-level mechanisms and the legislature.

For home work, the transition from informal to formal economy entails an understanding of the diversity of employers, workers, and intermediaries; creating legal and institutional mechanisms to improve access for informal workers to decent work; employment opportunities; labour protection; social protection; rights to organize for better learning and empowerment; promotion and development through collaboration between home workers, employers, and government agencies. This is in consonance with the proposals made by Chen $^{26}$ that the transition to the formal economy in the case of home workers

\footnotetext{
24 International Labour Organization, 2015, p. 4.

25 This covers protection, promotion, and development of informal workers as workers and as individuals, entrepreneurship, organization of workers, coordination of agencies at horizontal and vertical levels; employment policies that promote the generation of jobs in the formal economy, including supporting enterprises of all sizes, employment opportunity service for informal workers, and skills development policies that support lifelong learning; guarantee of rights according to fundamental principles including health, occupational health and safety, and social protection.

26 Martha A. Chen, "Informalization of labour markets: Is formalization the answer?", in S. Razavi (ed.), The Gendered Impacts of Liberalization: Towards "Embedded Liberalism"? (New York, 2009), pp. 191-218, pp. 207-08.
} 
implies the existence of regular employment; work and delivery based on clear contracts or documents that ensure legal compliance, timely remuneration, payment on a by-piece basis calculated in line with the minimum wage rate; occupational health and safety measures; home workers' ability to access funding for improving the working environment; and availability of infrastructure services including water, electricity, and sanitation for transforming homes into workplaces. All this complies with the provisions of Convention 117 and Recommendation 184, and may eventually lead to the formulation of a national policy related to home workers. Meanwhile Thailand's Home Workers Protection Act B.E. 2553 (2010) covers almost all of the above-mentioned points except access to funding. Although this category is not mentioned in the Act, in practice a fund exists specifically for home workers, as described above.

Although the transition to the formal economy is definitely beneficial for home workers, the diversity of workers and workplaces means that the transition will move at an unequal pace. Besides, a change to the formal economy means increased costs and small-sized businesses may not be able to shoulder greater burdens. There must be measures to support them and ensure that they can adjust accordingly. In this way, work will be guaranteed and workers can get access to basic rights. Further, the change is not something that can take place overnight. Other work-related dimensions must be taken into account, including cooperation from workplaces, workers, and government agencies. On the other side of the equation, not all business enterprises or workers can adjust to the formal economy. Some of them may be unable to do so. ${ }^{27}$

\subsection{Work and Remuneration of Home Workers: Implications for the Transition from Informal to Formal Economy}

In 2015, the author and a research team embarked on a study, "Setting Remuneration Rates for Home Workers in Thailand". 28 The objectives of the study were to study the work/production process, time used in the work process, and time required to complete tasks for twenty job categories (twentysix types of jobs) in seven industries; the average time used in work/production processes; and rates of remuneration to be used as a basis for calculating different remuneration rates for each type of job. The study adopted a survey

27 Ibid., p. 211.

28 Narumol Nirathron et al., Karnsuksakarnkumnod Uttrakatobtan Kongpurubnganpaitumteeban Naipratedtai [Study on Piece-Rate Setting for Home Workers in Thailand: A research report submitted to the Department of Labour Protection and Welfare] (Bangkok, 2015). 
approach in conjunction with inputs from academics, experts, stakeholders, and others from the government and private sector.

There were several constraints in the study process, ranging from defining the population to getting access to home workers and employers, all reflecting how challenging the transition to the formal economy could be. At the level of defining target samples, there were essentially no statistics available for reference on home workers. The sampling population was taken from lists of names of home workers and their employers compiled by the Department of Employment, Department of Labour Protection and Welfare, and Foundation for Labour and Employment Promotion, each having its own agenda for statistical compilation. The combined lists of the three organizations remained insufficient. Further network sampling and snowball sampling were required from home workers and local government agencies, including local government organizations and other local government offices under the Department of Employment, Department of Labour Protection and Welfare, and Community Development Department. Attempts were also made to coordinate with civil society, including the Lampang Ceramic Association, which worked in close contact with enterprises, contractors, and home workers in the ceramic industry in Lampang Province. At the same time, the list of employers compiled by the Department of Labour Protection and Welfare from 2013 to 2015, although fairly substantial, was found to be inadequate. Some employers were no longer in business, while others refused to divulge information. Efforts were made to collect more data, including from home workers, by searching the electronic media. This data collection by diverse means yielded a figure of 3,105 home workers and 226 employers across fifteen provinces in four regions of Thailand. The industries under study comprised: (1) food processing (peeling of toddy palms/ shallots [red onions]/water chestnuts/garlic cloves, and gutting of anchovies); (2) textiles (garments, clothing, sewing, weaving, seine-making, and embroidery of head scarves); (3) wood processing and basket work (bamboo and rattan wicker work for general use and for decoration); (4) paper products and artificial flowers (production/manufacturing of artificial flowers and garlands); (5) nonmetal products (bricks, flower pots, stone and plaster sculpting, glass and ceramic products); (6) metal products (knife-making and silver-crafting); and (7) miscellaneous (gemstone-cutting, leather goods, chemical products, rubber and plastic products, children's toys, souvenirs, bedding, electrical appliances, electronic parts, and woven products).

The study found similar characteristics for home workers as indicated in the 2007 survey and 2011 studies. ${ }^{29}$ In terms of work and income, the study revealed that 94.3 per cent of the samples accepted jobs from one source. Apart from

29 The study found that 80.7 per cent of home workers were female. Most were 40-49 years old (30.8 per cent), followed by 50-59 years (22.0 per cent), and 30-39 years (21.6 per 
home work assignments, other important sources of income derived from agriculture and general hired work. Three important suppliers of work were individual operators, contractors/intermediaries, and group representatives/leaders. Only twenty home workers or o.64 per cent claimed to have some kind of employment document. Most home workers received payment within seven days of work delivery. The number of workers who reported that there was no change in remuneration over the previous three years was almost the same as home workers who stated that they received higher payments, while some workers received lower remuneration.

Of the twenty-six types of jobs examined in the study, sixteen paid less than minimum wage, including jobs related to food processing and the seine industry. Jobs paying higher than minimum wages were skill-related, such as garments, chicken coops, artificial flowers, doll-making, gem-cutting, plastic basket work, and ceramic moulding, or involved hard work, such as soil preparation, knife-making, and mortar-rolling. A study of the work process showed that most of the jobs could be completed within a day, but some jobs took longer to complete, such as basket work and weaving. The working time for these types of jobs was more difficult to calculate. In some types of jobs, the hirer supplied materials and equipment, and the home worker was not required to pay for them. For home workers who used their own materials, remuneration often did not include the cost of materials.

Thirty-five per cent of home workers joined group memberships, with benefits including loan facilities, training opportunities, and funding support for vocational purposes. Those who were not group members gave the following reasons for not joining: lack of time, lack of awareness of opportunities, and no apparent prospective benefits. A large proportion of home workers, 48.9 per cent, averred that they should participate in fixing remuneration rates, and stated that the main problems they faced in their work were occupational safety and health, lack of regular job supply, low remuneration, and inadequate space at the workplace.

Most of the employers were female, too, aged between $5^{\circ}$ and 59 . Business owners accounted for the highest proportion among them, followed by group chairpersons. Most of the businesses were private operations, registered or unregistered community enterprises, and companies. The varying conditions of operation among these work suppliers led to differing relationships with the home workers. The reasons for the employers assigning them work

cent). For 64.5 per cent of home workers, primary school was the highest level of education, while 18.1 per cent completed lower secondary school. 
included making use of local networks, cost reduction, maintaining low inventory levels, coping with high production demands, outsourcing work not produced by their plants, easing labour shortage problems, and utilizing home worker expertise. Nearly all the employers believed that the wages they paid were appropriate, and most of them disagreed with the notion of adhering to minimum wage laws for home workers. Instead, they asserted, remuneration should be based on actual production time; other considerations could include complexity of work, product price and cost, and mutual agreements reached between employers and home workers including on minimum wages. They were of the opinion that remuneration should be determined by employers and home workers, with input from the government sector and experts. Most employers believed that adhering to the minimum wage rate would lead to an adverse impact. They expected the government to develop measures to mitigate such impact, including lower taxes, compensation for cost differences, and price controls for raw materials.

\subsection{Challenges and Opportunities in the Transition to the Formal Economy: Conclusion and Recommendations}

Judging from the proposed work standards under Convention 177 and Recommendation 184, as well as the overall home work situation in Thailand, work protection and social protection mechanisms, proposed guidelines for transition from the informal to the formal economy, and the study of work processes and home worker remuneration in 2015 , it can be concluded that longstanding efforts have been made to protect home workers. Although there have been no formally announced protection mechanisms, movements to advance protection have led to productive results, even before the passage of the Labour Protection Act of 1998. That law makes it clear that home work can be accorded labour protection by ministerial regulations distinct from those generally practised. The Ministerial Regulation on Protection of Home Workers in 2004 and the Home Workers Protection Act that followed in 2010 may be said to have significant implications, by no longer placing the issue solely in governmental hands. A number of international organizations have supported different studies, leading to institutional development and creation of non-governmental organizations ( $\mathrm{NGOS}$ ), and triggering movements for protecting, promoting, and developing home workers, thereby strengthening efforts towards the transition from the informal to the formal economy. The current study by the Home Work Protection Committee for the enforcement of the Home Workers Protection Act is also supported by the ILO. 
A number of challenges and opportunities remain for the transition to the formal economy that merit consideration:

1. The foremost challenge is the lack of clear statistics on home workers. Statistics collected by Ministry of Labour agencies do not reflect the real situation of home work, as they are collected for a specific purpose, namely to form groups. In practice there is a real need to conduct a survey of the situation, enumerating home workers and employers, remuneration problems, occupational safety and health, and development needs, to ensure protection, promotion, and development as prescribed by law. Therefore, statistics are an important foundation on which a national home workers policy can be built in accordance with Convention 177.

2. Lack of information on types of work, employment, home workers, and employers. This study confirms that (sub)contracting has spread to several production jobs, including the manufacture of very costly as well as inexpensive products. Information on types of work, employment, and employers is crucial for enabling access to the diverse home workers and employers described in this study. Employers include industries with formal production, personal enterprises, and community enterprises with an informal structure. Home workers differ in age, educational level, and skills. Local agencies are important sources of information on home workers and employers. This is especially pertinent when employers and contractors are local residents. The study also reveals that almost all home workers lack employment documents, reflecting their lack of understanding about worker rights as well as the inequalities in bargaining power between home workers and employers.

3. Lack of information on the role of the intermediary. The study provides insight into the important role of the intermediary, or production subcontracting party, relating to the remuneration received by home workers. Setting fair remuneration rates does not guarantee that the home workers will receive fair payment, as production process stakeholders are not limited to home workers and employers. For this reason, Convention 177 stresses a clear role for the intermediary, while Thailand's Home Workers Protection Act B.E. 2553 (2010) does not attach much importance to this role in terms of setting remuneration rates.

4. The Home Workers Protection Act B.E. 2553 (2010) is incomplete and not adequately enforced. There are still no secondary protective laws on occupational safety and health. Employers and home workers are often unaware of the existence of such laws or deliberately avoid compliance. Many employers are small-sized businesses and community enterprises that may have certain limitations to complying with the law, especially in the areas of remuneration and occupational safety and health. On the home workers' side, it is 
difficult to form groups and organizations as the workers are widely scattered and the employers still oppose such unions. Finally, the guarantee of regular work supply is influenced by the economic situation, and is beyond the control of agencies responsible for protecting, promoting, and developing home workers.

5. The persistence of problems and obstacles encountered by home workers. The most serious problems identified by home workers continue to be related to their health and regular work supply, not remuneration. The assistance they most need is regular work supply, remuneration protection, and funding. In most cases, these are beyond the control of agencies concerned with protection, promotion, and development. Regular work supply is just one example. At the same time, protection efforts can lead to greater severity of problems, especially when protection means higher costs with no measures in place to support employer adjustment. Certainly, some problems can be managed by means of the existing support system: for example, assistance in access to funding.

Due to the complex interconnectedness of these issues, coupled with conditions beyond individual control, the transition of home work to the formal economy must proceed with caution. It is also necessary to take into account the diversity of home workers and employers, and different types of work engagement, all reflecting different levels of readiness for the transition to the formal economy. In addition, it is important to understand how consumers seek inexpensive products without realizing that it may be related to labour exploitation.

In terms of opportunities, the results included the following:

1. Local governmental agencies can get access to residents at grassroot levels, such as local community development agencies, agencies promoting non-formal and informal education, and Ministry of Labour agencies. These agencies also work under the supervision of provincial governors in addition to their regular duties, making it possible to collect information on home workers, get access to them, and embark on the task of their promotion and development.

2. There is regular cooperation between government agencies, civil society, and international organizations, as seen in the project called Rural Women Workers in the Putting-out System. Undertaken during 1988-96, the project had a significant impact on knowledge generation and institutional development. The tripartite Home Work Protection Committee can also play an important role in simultaneously protecting, promoting, and developing home workers and promoting employers.

3. Workers in Thailand enjoy fairly comprehensive social protection. Although social security benefits to which home workers are entitled as 
insured persons may not be as generous as for formal workers, ${ }^{30}$ constant attempts have been made by the government and civil society to advocate for additional benefits. ${ }^{31}$ There is also a national health insurance system covering medical care and welfare, in addition to services offering informal education and vocational development. Different studies in some of the provinces reveal that these services can help promote vocational development. Lastly, although regular work supply lies beyond the control of agencies responsible for protecting, promoting, and developing home workers, social protection systems and mechanisms exist to provide support to home workers in skills development, acting as important devices to help them adapt suitably. In terms of home worker development, a Home Worker Fund ensures that promotion and development opportunities will be offered.

The following recommendations are made for the transition of home work to the formal economy, taking into consideration the development of home work protection and promotion, challenges and opportunities.

1. There must be a campaign to convey information about home worker protection directly to stakeholders, including employers, contractors, and intermediaries, about roles, duties, and legal responsibilities. The general public as consumers must properly understand the situation of this group of workers who can be exploited by efforts to reduce production costs and produce cheaper goods.

2. Systematic efforts should be made to survey and compile statistics on home workers and to distribute these to the general public. Local agencies should also participate in collecting data about home workers and employers as well as types of work and employment.

3. Studies should be conducted on home work according to different industries, especially those using a high proportion of home workers, such as textiles and jewellery, and those with low remuneration rates, such as farming. Areaspecific studies should also be encouraged. All this will help to create better understanding of the situation and the supply chain of the home-based system in Thailand, particularly in terms of the roles, duties, and responsibilities of stakeholders in the supply chain, involving employers, home workers, and intermediaries. It will also help to encourage industries that are ready for the transition to the formal economy.

30 Employees in formal establishments are entitled to seven types of benefits: sickness (nonwork-related sickness), maternity, invalidity, death, and survivors' benefits; child allowances; retirement benefits; and unemployment insurance.

31 In 2018, the third payment option was introduced. Workers who choose option 3 are entitled to five types of benefits. 
4. Local agencies should be encouraged to collect information on home workers and employers (if possible). In addition, local civil society can play a significant role, as seen in the case of the ceramic association which has information on home workers and employers in the ceramic industry in Lampang Province, in making it possible to access employers, intermediaries, and home workers. Such cooperation will lend useful support to protecting, promoting, and developing home workers.

5. Efforts should be made to encourage home workers forming groups or organizations and to strengthen existing ones, including studying conditions conducive to empowerment and improved working conditions in specific categories.

6. Importance must be attached to protecting occupational safety and health through legal measures and cooperating with local agencies to obtain such advice.

7. Labour protection should be extended to cover group formation and group empowerment to strengthen home workers' bargaining powers, integrating with the work of other agencies especially concerned with promoting and improving home worker knowledge and skills, to be readily equipped when there is a change of employment. 